\title{
Kwestia ochrony rolnictwa rodzinnego w systemie rolniczego ubezpieczenia spotecznego
}

The issue of protection of family-based farming in the system of agricultural social security

Ubezpieczenie od wypadków przy pracy w rolnictwie, wraz z ubezpieczeniem chorobowym i macierzyńskim, w powiązaniu z ubezpieczeniem emerytalno-rentowym ${ }^{1}$, składają się na odrębny od powszechnego system ubezpieczenia społecznego rolników, który stanowi dziś zasadniczy człon rolniczego prawa socjalnego. Zakres podmiotowy ubezpieczenia obejmuje obecnie przede wszystkim samozatrudnionych rolników ${ }^{2} \mathrm{i}$ członków ich rodzin³ ${ }^{3}$.

Mając na uwadze istotę i funkcje ubezpieczeń społecznych, pożądane jest, by ubezpieczenie to obejmowało swoim zakresem podmioty faktycznie pracujące w rolnictwie i przyznawało prawo do świadczeń we wszystkich sytuacjach grożących utratą zdolności do pracy. Prowadzona działalność rolnicza lub pomoc przy jej wykonywaniu stanowi tu bowiem podstawę podlegania ubezpieczeniu. Jego zakres podmiotowy wyznaczają definicje skonstruowane w ustawie o ubezpieczeniu społecznym rolników. Chodzi tu o podmioty pracujące w rolnictwie, a ściślej - prowadzące działalność rolniczą w gospodarstwie rolnym (często rodzinnym) i pozostające poza stosunkiem pracy.

\footnotetext{
${ }^{1}$ Związek ten występuje także z ubezpieczeniem emerytalno-rentowym, a uwidacznia się w katalogu świadczeń.

${ }^{2}$ Także pod pewnymi warunkami rolników-przedsiębiorców i pomocnika rolnika.

${ }_{3}^{3}$ Obowiązujące od dnia 18 maja 2018 r. znowelizowane przepisy w zakresie ubezpieczenia społecznego rolników wprowadzają do katalogu ubezpieczonych pomocnika, z którym rolnik zawarł cywilnoprawną umowę o pomocy przy zbiorach, zob. art. 1 ust 1 a. ustawy z dnia 13 kwietnia 2018 r o zmianie ustawy o ubezpieczeniu społecznym rolników oraz niektórych innych ustaw.
} 
Tytuł opracowania wymaga komentarza. Wyrażenie „rolnictwo rodzinne” użyte zostało dla podkreślenia szczególnego, podmiotowego charakteru ochrony, która powinna przysługiwać rolnikom i członkom ich rodzin w systemie rolniczego ubezpieczenia społecznego. Przedmiotem rozważań jest bowiem nie tyle ochrona gospodarstwa rodzinnego w ujęciu przedmiotowym jako jednostki produkcyjnej, lecz podmiotów prowadzących w nim działalność wytwórczą, istotnego elementu składowego, bez ochrony którego poważnie zagrożona jest jego dochodowość.

Zgodnie z art. 23 Konstytucji RP z 1997 r. podstawą ustroju rolnego państwa jest gospodarstwo rodzinne. Konstytucyjne uznanie „gospodarstwa rodzinnego” za podstawę ustroju odpowiada faktycznemu stanowi rzeczy, jaki ukształtował się w rozwoju historycznym naszego rolnictwa (Stalmachowski, 2013, s. 23-45). Uznanie gospodarstwa rolnego za „podstawę" ustroju oznacza, że jest ono jego „Zasadniczym elementem” (Lichorowicz, 2000). Norma konstytucyjna daje wyraz przekonaniu, iż ten stan rzeczy ma być utrzymany nie tylko teraz, ale także w przyszłości (Zdziennicki, 2015, s. 61-65).

Kwestia ochrony gospodarstw rodzinnych wiąże się z potrzebą ochrony rodziny, którą należy identyfikować z instytucją małżeństwa, więzami krwi, więzią emocjonalną a także prawną. Wskazany w Konstytucji model gospodarstwa rodzinnego współtworzą więc zarówno elementy o charakterze przedmiotowym, jak i podmiotowym.

Celem opracowania jest odpowiedź na pytanie, w jakim zakresie system rolniczego ubezpieczenia społecznego chroni rolnictwo rodzinne. Chodzi tu przede wszystkim o zagadnienie ochrony rodziny, która prowadząc gospodarstwo rolne,zapewnia sobie utrzymanie. Dla realizacji wskazanego celu należy przeanalizować pojęcia gospodarstwa rodzinnego w prawie polskim. Następnie konieczne będzie ukazanie katalogu podmiotowego ubezpieczenia społecznego rolników. Kwestie te łączą się ściśle z przedmiotem ochrony ubezpieczenia i nie sposób je rozważyć w oderwaniu od swoistości prowadzenia działalności rolniczej w rodzinnych gospodarstwach rolnych.

1. W ramach ustroju społeczno-gospodarczego wyróżnić należy ustrój rolny, którego podstawę stanowią gospodarstwa rodzinne (Domańska, 2001, s. 137). Ustrój rolny w doktrynie prawa rolnego określa się jako układ stosunków własnościowych i form organizacji produkcji w rolnictwie. B. Zdziennicki wskazuje, że art. 23 zd. 1 Konstytucji RP przesądza tylko o tym, że ustawodawca zwykły powinien tworzyć takie rozwiązania prawnorolne, które zapewniają gospodarstwom rodzinnym odpowiednie warunki do istnienia i rozwoju (Czechowski, Korzycka-Iwanow, Prutis \& Stelmachowski, 1999, s. 19). Wszystkie działania 
ustawodawcze wspierające gospodarstwo rodzinne są możliwe tylko w takich formach, które nie naruszają prawa własności i prawa dziedziczenia (art. 21 Konstytucji) oraz zasady wolności gospodarczej (art. 22 Konstytucji) (Zdziennicki, 2013, s. 60). Są to swoistego rodzaju wytyczne, które powinny być uszanowane przy wprowadzaniu w ustawodawstwie zwykłym przepisów regulujących status prawny gospodarstwa rodzinnego.

Oparcie ustroju rolnego na kategorii gospodarstwa rodzinnego nie oznacza oczywiście zakazu funkcjonowania innych typów gospodarstw rolnych. Wśród wszystkich gospodarstw prowadzonych przez producentów rolnych Konstytucja wyróżnia więc szczególne gospodarstwo rolne w postaci gospodarstwa rodzinnego, powstałego ze ścisłego połączenia gospodarstwa rolnego z gospodarstwem domowym. Konstytucyjny model gospodarstwa rodzinnego łączy w sobie elementy podmiotowe (rodzinne) z elementami przedmiotowymi (gospodarstwo). Gospodarstwo rodzinne rozumiane jest jako gospodarstwo zapewniające utrzymanie rodzinie rolnika (Winczorek, 2000, s. 36). Są to z pewnością gospodarstwa, które opierają swoje funkcjonowanie na pracy własnej rolnika i członków jego rodziny. Niejednokrotnie będą to także wielopokoleniowe gospodarstwa rolne. Mogą to być także gospodarstwa socjalne, o charakterze zaopatrzeniowym, które praktycznie nie produkują na rynek. Działalność rolnicza winna być prowadzona przede wszystkim w gospodarstwach rodzinnych, a ewentualne instrumenty wsparcia powinno się ustanawiać właśnie na ich rzecz. Szczególna ochrona tego typu gospodarstw w innych aktach prawnych nie powinna budzić wątpliwości.

Powstaje zatem pytanie, na ile wyrazem tej ochrony może być szczególny subsystem ubezpieczenia społecznego. Podmiotem zbiorowym (wspólnotą jednostek) prowadzącym gospodarstwo rodzinne powinna być przede wszystkim rodzina. $\mathrm{Z}$ ustrojowego punktu widzenia jest więc istotne, kto prowadzi gospodarstwo stanowiące podstawę ustroju rolnego (Rakoczy, 2015, s. 29). W odniesieniu do tej kategorii gospodarstw znaczenie będzie miało zatem swoiste powiązanie ochrony gospodarstwa rodzinnego z potrzebą ochrony rodziny przewidzianą w art. 18 ustawy zasadniczej.

Szczególny system rolniczego ubezpieczenia społecznego różni się zasadniczo od ubezpieczenia powszechnego. Jako typowo branżowe ubezpieczenie społeczne, oparte na zasadach solidarności grupowej, powstało ono z konieczności zapewnienia ochrony grupie podmiotów pracujących w jednej z najniebezpieczniejszych działalności zawodowych. Ochrona przed skutkami zajścia zdarzeń losowych w odniesieniu do zdolności produkcyjnych rolnika i członków jego rodziny jest argumentem uzasadniającym funkcjonowanie subsystemu rolniczego ubezpieczenia społecznego. Wraz z funkcjami tego ubezpieczenia realizuje ono bowiem 
konstytucyjny obowiązek ochrony osób pracujących w działalności rolniczej. Na szczególną uwagę zasługują tu uwarunkowania historyczne - pozbawienie w przeszłości ochrony socjalnej rolników, specyficznie zakreślony katalog podmiotów podlegających ubezpieczeniu i pracujących w tej działalności, oraz kwestie obciążeń składkowych i finansowania świadczeń.

System rolniczego ubezpieczenia społecznego w założeniu powinien zatem chronić element podmiotowy gospodarstwa - rolnika i członków jego rodziny bez którego niemożliwe jest prowadzenie działalności rolniczej. Ze względu na zjawisko wypadkowości w rolnictwie i inne kategorie ryzyka socjalnego ubezpieczenie społeczne ma istotne znaczenie dla ochrony gospodarstwa rodzinnego. Realizacja tej ochrony widoczna jest w konstrukcji ubezpieczeń - przedmiocie ochrony i funkcjach, jakie powinno ono pełnić.

Pracujący w gospodarstwach rolnych rolnicy mają prawo do zabezpieczenia społecznego w razie niezdolności do pracy i na wypadek inwalidztwa - art. 67 ust. 1 Konstytucji RP. Ochrona wskazanych w ustawie zasadniczej sytuacji życiowych realizowana jest dla analizowanych podmiotów nie tylko metodą ubezpieczeniową, lecz ma dziś charakter złożony i dokonywana jest praktycznie za pomocą wszystkich metod zabezpieczenia społecznego. Na podstawie umocowania w normie prawnej z art. 67 Konstytucji funkcjonuje w Polsce system ubezpieczenia społecznego, zarówno powszechnego, jak i rolniczego. Ochronie podlegają wszyscy obywatele polscy, jest więc ona powszechna i obejmuje wszystkie zdarzenia zagrażające niezdolności do pracy (Jędrasik-Jankowska, 2003, s. 21). Konstytucja wyraźnie wskazuje jednak, że materia ubezpieczenia społecznego regulowana jest ustawami specjalnie w tym celu wydawanymi (przede wszystkim ustawą o systemie ubezpieczeń społecznych, t.j. Dz.U. 2019, poz. 300 z późn. zm i ustawą o ubezpieczeniu społecznym rolników, t.j. Dz.U. 2020, poz. 174).

W przypadku rolnictwa i zabezpieczenia społecznego rolników wskazana powyżej norma konstytucyjna wiąże się ściśle z normą z art. 23 i 18 Konstytucji. Można się tu doszukiwać nie tylko uzasadnienia dla argumentacji co do istnienia szczególnego subsystemu rolniczego ubezpieczenia społecznego, lecz przede wszystkim potrzeby, a nawet konieczności, skonstruowania w polskim ustawodawstwie racjonalnych i skutecznych reguł ochrony gospodarstw, nie tylko ze względów przedmiotowych, ale przede wszystkim podmiotowych. Istnieje bowiem w gospodarstwach rodzinnych szczególna potrzeba ochrony ryzyka socjalnego.

Wiązało się to zawsze z istotą rolnictwa rodzinnego jako zjawiska społeczno-ekonomicznego. Rodzinne gospodarstwo rolne charakteryzują przede wszystkim trzy cechy: ścisłe powiązanie gospodarstwa rolnego (produkcyjnego) z gospo- 
darstwem domowym, współzależność rozwoju rodziny i gospodarstwa rolnego oraz swoistość pracy rodziny w gospodarstwie rolnym (Budzinowski, 1985, s. 65). O specyficznych cechach pracy rolniczej przesądza przede wszystkim: brak ram czasowych i zmienność warunków jej wykonywania, wielozadaniowość i sezonowość oraz często konieczność korzystania z pomocy osób najbliższych, w tym także dzieci. Z drugiej strony nie można pominąć faktu zróżnicowania gospodarstw rolnych. Świadczą o tym nie tylko względy obszarowe, wyposażenie, urządzenia techniczne czy liczba osób pracujących. Znaczenie mają tu przede wszystkim rozmiary produkcji (Kremer, 2004, s. 340). Należy także pamiętać, że nie wszystkie gospodarstwa indywidualne mogą posiadać status gospodarstw rodzinnych.

2. Definicja gospodarstwa rodzinnego w polskim ustawodawstwie rolnym budzi wiele zastrzeżeń, a prawna problematyka rodzinnego charakteru gospodarstwa rolnego jest niezwykle szeroka i złożona. Obejmuje ona cały szereg zagadnień szczegółowych, dotyczących zarówno organizacji oraz funkcjonowania gospodarstwa rolnego, jak i funkcjonowania rodziny na podstawie przepisów prawa rodzinnego, rolnego, cywilnego (Budzinowski, 1985, s. 64) oraz zabezpieczenia społecznego.

Pierwsze rozwiązanie określające prawny status gospodarstw rodzinnych, ustanowione w ustawie z 11 kwietnia 2003 r., należy uznać za śladowe. Abstrahując od faktu, że jest to definicja z punktu widzenia techniki legislacyjnej mało udana (w skład definiensu wchodzą odesłania do dwóch dalszych definicji legalnych i to, co gorsza, o podobnym zakresie), zastrzeżenia budzą przede wszystkim podane w niej kryteria ustalenia rodzinnego charakteru gospodarstwa rolnego. Kryteria te są w znacznym stopniu odmienne od kryteriów uznania gospodarstwa za rodzinne, stosowanych w ustawodawstwach krajów Europy Zachodniej (Lichorowicz, 2005, s. 28-29). Stało się tak dlatego, iż definicję gospodarstwa rodzinnego skonstruowano „na marginesie” głównego celu ustawy, jakim jest kontrola obrotu nieruchomościami (Prutis, 2015, s. 17).

Przykładowo w ustawodawstwie niemieckim pojęcie gospodarstwa rodzinnego wyróżniano, opierając się na kryterium czasu pracy, które implikuje nie tylko dolne, ale i górne granice jego wielkości. Gospodarstwa takie powinny dać nie tylko podstawę utrzymania rodzinie rolniczej, lecz także zapewnić zatrudnienie jej członków (Lichorowicz, 2015, s. 186). Z kolei w ustawodawstwie włoskim, obok wymogu poświęcania pracy w rolnictwie $50 \%$ czasu pracy i uzyskiwania $\mathrm{z}$ tego tytułu co najmniej $50 \%$ dochodu, wymaga się od rolnika ustawowo określonych kwalifikacji zawodowych. W Hiszpanii uznano, że produkcja w gospodarstwie rodzinnym winna mieć charakter towarowy, dochody z niej zaś powinny stanowić 
podstawowe źródło utrzymania rodziny rolniczej na poziomie analogicznym do innych gałęzi gospodarki, a funkcjonowanie gospodarstwa winno opierać się na pracy osobistej prowadzącego i jego rodziny (Lichorowicz, 2015, s. 183-184).

Aktualna polska regulacja prawna jedynie nominalnie operuje pojęciem gospodarstwa rodzinnego, albowiem sformułowana przez ustawodawcę definicja w art. 5 ustawy z dnia 11 kwietnia 2003 r. o kształtowaniu ustroju rolnego (t.j. Dz.U. 2019, poz. 1362) nie zawiera jakichkolwiek odniesień do „rodzinnego” charakteru gospodarstwa. Wszelkie przesłanki podmiotowe (kwalifikacje rolnicze, zameldowanie, a szczególnie osobiste prowadzenie gospodarstwa jako podejmowanie wszelkich decyzji) dotyczą pojedynczej osoby fizycznej prowadzącej gospodarstwo. Jest to zatem definicja gospodarstwa indywidualnego w znaczeniu - prowadzonego jednoosobowo, a nie definicja gospodarstwa rodzinnego, chyba że przyjmie się, iż wyznacznikiem gospodarstwa rodzinnego jest sama jego powierzchnia - nie więcej niż 300 ha użytków rolnych (Prutis, 2005, s. 176-177).

Jednym z największych wyzwań nauki prawa rolnego jest dziś zatem sformułowanie takiej definicji gospodarstwa rodzinnego, która pogodziłaby często sprzeczne interesy zróżnicowanego polskiego rolnictwa. Aktualnie przesłanki obszarowe z ustawy o kształtowaniu ustroju rolnego (u.k.u.r.) - do 300 ha spełnia w Polsce ponad 99\% gospodarstw rolnych (dane Ministerstwa Rolnictwa i Rozwoju Wsi). Nie można jednak w polskim ustawodawstwie tworzyć definicji legalnych dla realiów, jakie aktualnie występują. Nie wszystkie przecież gospodarstwa do 300 ha posiadają cechy gospodarstw rodzinnych. Takiej zależności zdaje się nie dostrzegać polski ustawodawca.

Aktualna definicja ustawowa gospodarstwa rodzinnego stanowi jedynie grę pozorów. Nie ustanowiono jej w akcie prawnym mającym na celu ochronę wsparcie tej kategorii gospodarstw. Nie odwołuje się także do atrybutów rodzinności w działalności rolniczej. Przyjęte kryterium obszarowe nie odpowiada ani potrzebom, ani możliwościom typowej rodziny rolniczej. Warto jednak zauważyć, że gospodarstwo o powierzchni zbliżonej do minimalnej nie zapewni rodzinie rolnika odpowiedniego poziomu dochodów; gospodarstwo o powierzchni zbliżonej do maksymalnej wymaga natomiast korzystania z dodatkowej pracy osób nienależących do rodziny (Prutis, 2015, s. 12).

Żaden polski akt prawny nie określa wzajemnych relacji poszczególnych kategorii gospodarstw rolnych - gospodarstwo rolne, indywidualne, a raczej prywatne gospodarstwo rolne, gospodarstwo rodzinne. Likwidacja kategorii własności indywidualnej w naszym porządku prawnym dotyczy także rolnictwa, które „stało się" rolnictwem prywatnym (Prutis, 2015, s. 20). Nierzadko w publikacjach używa się zamiennie tych terminów, a przecież nie są one tożsame. Nie każde 
gospodarstwo rolne jest prowadzone przez producentów rolnych wykonujących działalność rolniczą na własny rachunek, podlegających szczególnej regulacji rolniczego ubezpieczenia społecznego i pozostających poza stosunkiem pracy. Nie każde gospodarstwo indywidualne będzie gospodarstwem rodzinnym. Warto zauważyć, że istnieją także „gospodarstwa nieindywidualne” oraz nadal mogą występować gospodarstwa rolne stanowiące własność publiczną. Nie sposób także nie zauważyć mnogości i nieprecyzyjności definicji gospodarstwa rolnego w innych aktach prawnych z kodeksem cywilnym włącznie.

Zbyt ogólne określenie definicji ustawowej nie służy ochronie gospodarstw rodzinnych. Polskie gospodarstwa rolne są dziś mocno zróżnicowane. Definicja z u.k.u.r. posługuje się kryterium przedmiotowym, czyli obszarem użytków rolnych, oraz podmiotowym, polegającym na umieszczeniu rolnika indywidualnego w treści normatywnej gospodarstwa rodzinnego. Nie jest to kryterium, które może służyć rozgraniczaniu gospodarstw rodzinnych od innych gospodarstw rolnych. Definicja gospodarstwa rodzinnego, zawarta w u.k.u.r., akcentująca przede wszystkim wymagania obszarowe oraz te dotyczące miejsca zamieszkania rolnika, a także podkreślająca wymagania stabilności zarówno w zakresie miejsca zamieszkania, jak i osobistego prowadzenia gospodarstwa oraz doniosłość wyłącznie praktycznych kwalifikacji rolniczych, w bardzo małym zakresie pokrywa się z konstytucyjnym wzorcem. Mimo to analizowana definicja chroni przed powstawaniem wielkoobszarowych gospodarstw rolnych (Wierzbowski, 2015, s. 369).

3. Istnieje zatem potrzeba określenia racjonalnych legalnych kryteriów wyróżnienia tej kategorii gospodarstw, mając na względzie swoiste cechy gospodarstwa rodzinnego (Puślecki, 2016, s. 207). Należy tego dokonać przy uwzględnieniu poniżej wskazanych zależności.

Do definiowania gospodarstw rodzinnych w różnych naukach wskazuje się różnorodne kryteria o charakterze ekonomicznym, społecznym czy kulturowym. Przyjmuje się korzystanie z rodzinnych zasobów pracy, zarządzanie gospodarstwem przez członka rodziny, jak również uwzględnia się wielkość posiadanego gospodarstwa lub wielkość wytwarzanej produkcji rolnej. W ekonomicznej definicji gospodarstwa rodzinnego bardzo silnie zaznaczone są związki pomiędzy gospodarstwem a użytkującą je rodziną. „Gospodarstwo rodzinne to: "samodzielna jednostka produkcyjna, gdzie podstawowe czynniki produkcji należą do właściciela (głowy rodziny), który wypełnia funkcje kierownicze; praca wykonywana jest głównie przez właściciela i jego rodzinę; własność i zarządzanie przekazywane są z pokolenia na pokolenie; gospodarstwo domowe 
nie jest oddzielone od jednostki produkcyjnej, a wynikiem gospodarowania jest dochód «" (Woś, 1998, s. 144).

Prawne pojęcie gospodarstwa rodzinnego jest nierozerwalnie związane z pojęciem gospodarstwa rolnego, w którym się zawiera. Mnogość definicji gospodarstwa rolnego i jednocześnie ich nieprecyzyjność w prawie polskim nie ułatwi w przyszłości zadania legislacyjnego.

Wyznacznikiem gospodarstwa rodzinnego są stosunki własnościowe w rolnictwie. Chodzi tu o własność gospodarstwa jako zespołu środków potrzebnych do prowadzenia działalności rolniczej. Podmioty pracujące w gospodarstwach rodzinnych to przede wszystkim właściciele posiadanego majątku produkcyjnego, którzy z całymi rodzinami mieszkają na terenie gospodarstwa rolnego ${ }^{4}$. Przekazywanie gospodarstw indywidualnych z pokolenia na pokolenie jest jednym z najbardziej charakterystycznych wyróżników gospodarstw rodzinnych.

Ochrona gospodarstw rodzinnych wiąże się z zagadnieniem ochrony rodziny, która, prowadząc gospodarstwo rolne, zapewnia sobie utrzymanie. Działalność rolnicza w takich gospodarstwach opiera się na pracy członków rodziny i jest to najistotniejszy składnik zapewniający prawidłowe funkcjonowanie owych gospodarstw. Podstawowy zasób pracy obejmuje zatem osoby tworzące wspólne gospodarstwo domowe. Obowiązki w gospodarstwie rolnym są rozdzielane przez „rolnika zarządzającego” pomiędzy wszystkich członków rodziny, nie wykluczając siebie i dzieci.

Dochód naturalny osiągany z rodzinnej działalności rolniczej powinien stanowić podstawę utrzymania rodziny. Nawet wtedy, kiedy rolnik nie wytwarza produkcji z przeznaczeniem na rynek, gospodarstwo stanowi często jedyne zabezpieczenie bytu rodziny (gospodarstwa samozaopatrzeniowe - socjalne). Wykluczyć zatem należy w zasadzie dochody z innych źródeł, jeżeli nie będą miały charakteru dodatkowego, wspierającego, lecz dominujący w uzyskaniu dochodu - kategoria rolnika-przedsiębiorcy - dwuzawodowca.

W zbiorze prywatnych gospodarstw rolnych wyróżnić można następujące grupy gospodarstw rodzinnych: towarowe - produkujące głównie na rynek, niskotowarowe - przeznaczające niewielką część produkcji na rynek, samozaopatrzeniowe - które nie występują na rynku i całą wytworzoną produkcję przeznaczają na bieżącą konsumpcję, agroturystyczne - pełniące funkcje wypoczynkowo-rekreacyjną, w których w zasadzie nie prowadzi się typowej produkcji rolnej. Warto jednak podkreślić, że z tych wszystkich wymienionych

\footnotetext{
${ }^{4}$ Nie można tu jednak zapomnieć o innych formach posiadania, które dotyczą przede wszystkim gruntów rolnych - użytkowaniu wieczystym, samoistnym posiadaniu czy dzierżawie.
} 
powyżej grup praktycznie tylko gospodarstwa samozaopatrzeniowe będą mogły być zawsze uznane za rodzinne.

Jeżeli chodzi o obecnie zastosowane w u.k.u.r. kryterium obszarowe, należy zauważyć, że istnieją zarówno małe, jak i duże gospodarstwa rodzinne. Gospodarstwa rodzinne z reguły utożsamia się z gospodarstwami o małej powierzchni lub też o niedużej wielkości ekonomicznej. Wielkoobszarowe gospodarstwa rolne nie dają często realnych możliwości korzystania z pracy członków rodziny, konieczne jest tu bowiem zatrudnianie pracowników.

Kryteria związków rodzinnych w rolnictwie, z uwagi na swoistość wykonywanej pracy, posłużyły niejednokrotnie do określania podmiotów podlegających ochronie zdolności do pracy w systemach rolniczego ubezpieczenia społecznego. Chodzi przede wszystkim o samozatrudnionych rolników i członków ich rodzin, a nie wszystkie osoby pracujące w rolnictwie (np. pracowników rolnych). Podmiotami tymi zgodnie z przepisami ustawy o ubezpieczeniu społecznym rolników jest rolnik, jego małżonek i domownik.

Mając na uwadze powyższe zależności, należy stanowczo stwierdzić, że najważniejszych cech rolnictwa rodzinnego polski ustawodawca zdaje się nie zauważać. Związek gospodarstwa rolnego z domowym, więzi rodzinne i potrzeba ochrony rodziny, wielopokoleniowość rodzin rolniczych, rodzinne zasoby pracy, ochrona zdolności do pracy w rolnictwie, stosunki własnościowe, rodzinne dochody oraz stosunki z następcą prawnym to istotne atrybuty rodzinnych gospodarstw rolnych (Puślecki, 2016, s. 201-207). Potrzeba szczególnej ochrony rodzinnego gospodarstwa rolnego $\mathrm{w}$ ujęciu przedmiotowym i funkcjonalnym z uwzględnieniem stosunków osobowych oraz osobiście świadczonej pracy została określona w art. 23, 18 i 67 Konstytucji.

4. Jeśli chodzi o konstrukcję polskiego systemu ubezpieczenia społecznego rolników, to ustawodawca powinien uwzględnić fakt, że podstawą ustroju rolnego państwa jest gospodarstwo rodzinne, i stwarzać takie warunki, aby regulacja prawna z zakresu ubezpieczenia społecznego rolników sprzyjała - a przynajmniej nie przeszkadzała - osiągnięciu legitymowanego konstytucyjnie celu (Wierzbowski, 2015, s. 369).

Szczególny subsystem rolniczego ubezpieczenia społecznego winien zatem poprzez przedmiot ochrony tego ubezpieczenia właściwie chronić element podmiotowy gospodarstwa rodzinnego. Nie ulega wątpliwości, że praca rolnika i jego rodziny jest podstawowym warunkiem możliwości prowadzenia działalności rolniczej w gospodarstwie rolnym. Można nawet iść nieco dalej i stwierdzić, że de facto przesądza ona o bycie, istnieniu gospodarstwa rolnego nie tylko teraz, lecz także w przyszłości. Nie można tutaj nie zauważyć, że nawet w aktualnej 
definicji kodeksowej z art. 55(3) k.c. ustawodawca, wymieniając grunty, urządzenia i inwentarz, a nawet prawa, pominął element podmiotowy - stosunki osobowe występujące w rolnictwie oraz osobiście świadczoną pracę członków rodziny w gospodarstwie rolnym.

Rolnik i jego rodzina to istotny składnik, bez którego nie da się prowadzić rodzinnej działalności rolniczej. Elementy te mają zatem istotne znaczenie do definiowania gospodarstwa rolnego nie tylko w ujęciu przedmiotowym, lecz także funkcjonalnym. Definicja z k.c. określa jednak ogólne pojęcie wszystkich kategorii gospodarstw rolnych. Szczególnie zatem należy ubolewać nad faktem, iż próżno dziś szukać wskazanych powyżej składników nawet w legalnej, aktualnie sformułowanej definicji gospodarstwa rodzinnego w u.k.u.r.

Nie ulega wątpliwości, że składnik podmiotowy jest podstawowym wyznacznikiem istnienia rolnictwa rodzinnego i prowadzenia rodzinnej działalności rolniczej.O możliwości wykonywania pracy w gospodarstwie rolnym nie świadczy posiadanie zdolności do czynności prawnych, lecz zdolność do wykonywania czynności składających się na działalność rolniczą w ogólności, pomoc przy jej wykonywaniu.

Pojęcie rolnika indywidualnego nie występuje w ustawie ubezpieczeniowej. Ustawodawca zarówno w tytule, jak i tekście ustawy konsekwentnie posługuje się pojęciem rolnika. Miało to zapewne służyć podkreśleniu nowego - również $\mathrm{z}$ ustrojowego punktu widzenia - podejścia do ubezpieczenia społecznego rolników. Przymiotnik ,indywidualny” zawierała poprzednio obowiązująca ustawa o ubezpieczeniu społecznym rolników. „W minionym ustroju - na poziomie konstytucyjnym - indywidualne gospodarstwa rodzinne opatrywano dodatkowym kwalifikatorem "pracujących chłopów «, zawężając w ten sposób gwarancje konstytucyjne" (Wierzbowski, 2015, s. 26-27). Ustawa nie operuje również pojęciem gospodarstwa rodzinnego czy rolnictwa rodzinnego. Co więcej, ustawowa definicja rolnika również pozbawiona jest atrybutów rodzinności. Przez rolnika ustawa ubezpieczeniowa nakazuje rozumieć pełnoletnią osobę fizyczną, zamieszkującą i prowadzącą na terytorium Rzeczypospolitej Polskiej, osobiście i na własny rachunek, działalność rolniczą w pozostającym w jej posiadaniu gospodarstwie rolnym, $\mathrm{w}$ tym również w ramach grupy producentów rolnych, a także osobę, która przeznaczyła grunty prowadzonego przez siebie gospodarstwa rolnego do zalesienia - zgodnie z art. 6 pkt 1 rolniczej ustawy ubezpieczeniowej. Należy zaznaczyć, że pomimo powyższej uwagi, jest to pojęcie szersze, które swym zakresem obejmuje także rolnictwo prywatne o rodzinnym charakterze. 
O katalogu ubezpieczonych w szczególnym subsystemie rolniczego ubezpieczenia społecznego decydować powinna nie tylko przynależność do wskazanej grupy zawodowej i warunki pracy w działalności rolniczej, lecz przede wszystkim praca rodziny i konieczność jej ochrony w wielopokoleniowym gospodarstwie rolnym.

Istotnym elementem w działalności rolniczej jest istnienie silnego, nierozerwalnego związku z gospodarstwem domowym. Wiąże się to nie tylko z problemami kwalifikacji zdarzeń ubezpieczeniowych, lecz także kwestią akceptacji pracy i pomocy dzieci rolnika w tym gospodarstwie (Puślecki, 2009; Król, 2015, s. 91-99). Nie można także zapominać, że istnieją w Polsce gospodarstwa o typowo socjalnym, zaopatrzeniowym charakterze, które nie funkcjonują wcale bądź tylko w marginalnym zakresie na rynku. To wyjątkowo swoista cecha działalności rolniczej - diametralnie odróżniająca rolnika od typowego przedsiębiorcy. Specyficzne są tu także kategorie ryzyka socjalnego, które towarzyszą tak zakreślonej działalności.

Ochrona zdolności do pracy rolnika zarządzającego i rozdzielającego pracę pomiędzy członków rodziny jest kwestią kluczową. Bardzo często wraz z małżonkiem stanowi on „siłę napędową" gospodarstwa. Kryteria ustawowe wymagają od rolnika, aby osobiście prowadził gospodarstwo rolne. $\mathrm{W}$ gospodarstwie rolnym podstawowy zasób pracy obejmuje zatem osoby tworzące wspólne gospodarstwo domowe - to istotny związek pomiędzy gospodarstwem domowym i rolnym. Dochód osiągany z działalności rolniczej powinien stanowić podstawę utrzymania rodziny. Nawet wówczas, kiedy rolnik nie produkuje z przeznaczeniem na rynek, gospodarstwo stanowi często jedyne zabezpieczenie bytu rodziny (gospodarstwa samozaopatrzeniowe - socjalne).

Pomijając problemy wynikające z niedoskonałości pojęć rolnika i małżonka rolnika w ustawie o ubezpieczeniu społecznym rolników (u.s.u.r), należy wskazać, że w ustawie ubezpieczeniowej ochrona rolnika i jego rodziny nie jest realizowana w sposób wystarczający (Puślecki, 2011). Należy ją rozpatrywać z punktu widzenia przedmiotu ochrony - zdolności do zdobywania własną pracą środków utrzymania, ale także ze względu niemożliwości pracy z powodu osiągnięcia wieku poprodukcyjnego. Podkreślając problemy wysokości świadczeń emerytalnych, należy zauważyć, że dla objęcia ubezpieczeniem społecznym rolników nie ma znaczenia ani dochód, ani wielkość gospodarstwa rolnego ${ }^{6}$. Mimo to w systemie nadal mogą funkcjonować osoby będące fikcyjnymi rolnikami, a zarazem nie

\footnotetext{
${ }^{5}$ Chodzi tu w szczególności o nieubezpieczone dzieci ulegające wypadkom przy pracy rolniczej.

${ }^{6}$ Poza wyższym wymiarem składek dla ubezpieczenia emerytalno-rentowego.
} 
wszyscy rolnicy prowadzący gospodarstwa rodzinne mogą być objęci ochroną w rolniczym ubezpieczeniu społecznym ze względu na możliwość wyłączenia z KRUS. Także nie wszyscy rolnicy indywidualni, w rozumieniu u.k.u.r., mogą być ubezpieczeni na starość i na wypadek niezdolności do pracy w systemie ubezpieczenia społecznego rolników (Wierzbowski, 2015).

Inaczej jest $\mathrm{w}$ ubezpieczeniu wypadkowym, chorobowym i macierzyńskim, mającym cechy urządzenia samopomocowego, opartego tylko na zasadzie solidarności grupowej, funkcjonującym bez wsparcia finansowego ze strony budżetu państwa. W ubezpieczeniu tym na wniosek może ubezpieczyć się każdy rolnik, jeżeli działalność rolnicza stanowi jego stałe (niekoniecznie jedyne) źródło utrzymania (art. 7 ust. 2 u.s.u.r.) (Wierzbowski, 2015, s. 371).

Warto zauważyć, że obecnie w katalogu ubezpieczonych znajduje się pomocnik rolnika. Ustawodawca, poszerzając katalog podmiotowy, stara się uwzględniać zmieniające się okoliczności społeczno-gospodarcze. Z drugiej jednak strony nie obejmuje ochroną wszystkich członków rodziny rolnika pracujących w gospodarstwie, pomimo normy konstytucyjnej uznającej gospodarstwa rodzinne za podstawę ustroju rolnego.

Choć ustawa o ubezpieczeniu społecznym rolników nie operuje pojęciem gospodarstwa rodzinnego ani rolnictwa rodzinnego, to jednak uwzględnia aspekty rodzinności w gospodarstwach rolnych. Wymiarem tego są konstrukcje pozwalające stosować przepisy ustawy w odniesieniu do małżonka rolnika, jak i domownika. Jak jednak wyżej wskazano, pojęcia te budzą tyle wątpliwości, że trudno mówić tu o właściwej ochronie tych podmiotów. Przykładem może być chociażby wymóg pracy małżonka wyłącznie w gospodarstwie domowym rolnika czy uznanie za domowników dzieci własnych dopiero od 16. roku życia. Jednocześnie domownikiem może być inna osoba bliska dla rolnika - nawet niespokrewniona - która oświadczy w KRUS, że stale pracuje w gospodarstwie rolnym i nie jest związana $\mathrm{z}$ rolnikiem stosunkiem pracy.

Ustawa o ubezpieczeniu społecznym rolników nie zapewnia zatem w wystarczającym zakresie ochrony ex ante jak i ex post, chociażby z tego powodu, że nie obejmuje wszystkich podmiotów faktycznie wykonujących pracę w działalności rolniczej. Znamiennym przykładem jest tu całkowite pozbawienie - nawet na wniosek - ochrony dzieci do 16. roku życia pomagających rolnikowi w pracach związanych z prowadzeniem gospodarstwa. W praktyce miarą określenia zdolności do pracy w rolnictwie jest faktyczna możliwość pomocy i nauki podczas wykonywania czynności składających się na działalność rolniczą. Zależność tę już dawno zauważyły ustawodawstwa takich krajów jak Włochy, Niemcy czy Francja (Puślecki, 2011), gdzie ubezpieczeniu podlegają dzieci bez względu na 
wiek. W Polsce to zagadnienie jest traktowane po macoszemu od roku 2004, kiedy pozbawiono dzieci możliwości korzystania ze świadczeń z ubezpieczenia rodziców w KRUS (Puślecki, 2018, s. 126).

Należy jednak nadmienić, że władze Funduszu Składkowego Ubezpieczenia Społecznego Rolników zawarły umowę z AGRO Ubezpieczenia - Ubezpieczenie Gospodarcze na grupowe ubezpieczenia następstw nieszczęśliwych wypadków i chorób dzieci osób objętych społecznym ubezpieczeniem rolników ${ }^{8}$. Koszty zawieranych umów finansowane są przez Fundusz Składkowy Ubezpieczenia Społecznego Rolników. Grupowe ubezpieczenie NNW obejmuje wyłącznie dzieci (do ukończenia 16. roku życia) rolników, pozostające we wspólnym gospodarstwie domowym z rodzicami lub opiekunami prawnymi, z których przynajmniej jedno podlega ubezpieczeniu społecznemu rolników w pełnym zakresie.

Jest to jednak ubezpieczenie gospodarcze i nie zapewnia takiej ochrony jak ubezpieczenie społeczne. Można stwierdzić, że przedstawiona konstrukcja stwarza jedynie pozory i powoduje niebezpieczeństwo utwierdzenia w przekonaniu o rozwiązaniu istniejącego od 2004 roku problemu ochrony dzieci przed utratą zdolności do pracy. Nie można jednak nie zauważyć, że jest to rozwiązanie fragmentaryczne i niekompletne. Nie zapewnia bowiem dzieciom odpowiedniej ochrony ex ante oraz ex post. Nie chroni zdolności do pracy, lecz życie i zdrowie dziecka przed skutkami nieszczęśliwych wypadków.

Kwestią wartą podniesienia jest problem zmiany generacji w rolnictwie. Sama idea stworzenia świadczenia emerytalno-rentowego $\mathrm{z}$ ubezpieczenia rolniczego niewątpliwie winna sprzyjać przyspieszeniu wymiany pokoleń $\mathrm{w}$ rolnictwie rodzinnym. Warunkiem podstawowym jest zaprzestanie prowadzenia działalności rolniczej. Niska wysokość emerytury rolniczej nie zawsze może jednak rekompensować starty poniesione w wyniku zaprzestania pracy przez osobę w wieku poprodukcyjnym. Często zatem emeryt, pomimo pobierania świadczenia, nadal pomaga dzieciom w gospodarstwie rolnym. Nie zawsze dzieje się tak z chęci świadczenia pomocy, lecz coraz częściej wynika z konieczności; w szczególności daje się to zauważyć w niskodochodowych, niewielodzietnych gospodarstwach rolnych.

W odniesieniu do rolnictwa przedmiot ochrony ubezpieczenia społecznego należy określać i analizować w sposób odmienny niż w porównaniu z sytuacją typowego pracownika. Nie chodzi tylko o listę zdarzeń mogących zagrażać czło-

${ }^{7}$ Aktualna umowa została zawarta 1 stycznia 2020 r. Po raz pierwszy została podpisana w 2016 r. z Ergo Hestia, następnie ubezpieczycielem zostało Pocztowe Towarzystwo Ubezpieczeń Wzajemnych.

${ }^{8}$ Suma ubezpieczenia wynosi 67 tys. złotych. 
wiekowi podczas wykonywania czynności składających się na działalność rolniczą, lecz przede wszystkim o szerszy katalog podmiotowy. Zagrożenia skutkujące utratą zdolności do pracy trzeba przewidywać, biorąc pod uwagę pracę rolnika i domowników, ze szczególnym uwzględnieniem pomagających dzieci i osób starszych. Nie ulega zatem wątpliwości, że przedmiot ochrony ubezpieczenia ściśle i swoiście łączy się z katalogiem podmiotów pracujących w rolnictwie.

Przedmiotem ochrony rolniczego ubezpieczenia społecznego jest ochrona przed skutkami zajścia zdarzeń losowych w odniesieniu do zdolności produkcyjnych rolnika i członków jego rodziny. $Z$ uwagi na silne więzi rodzinne występujące w produkcji rolnej istotnym zagadnieniem powinna być tu problematyka ochrony całej rodziny rolnika, a nie jedynie głównego żywiciela, jak dzieje się to w ubezpieczeniu powszechnym. Obecnie w zasadzie brak w analizowanym subsystemie takich instrumentów ochrony. Katalog podmiotowy wyraźnie wskazuje na osoby ubezpieczone, a nowelizacja ustawy ubezpieczeniowej z 2004 r. zlikwidowała całkowicie prawo do świadczeń dla osób, które w przypadku zdarzenia losowego korzystały z ubezpieczenia rolnika.

5. Przeprowadzone rozważania uzasadniają sformułowanie następujących wniosków.

Obowiązująca regulacja prawna nie zapewnia odpowiednich warunków preferencyjnych dla funkcjonowania gospodarstw rodzinnych. Ponadto w niewystarczający sposób gwarantuje trwałość gospodarowania w rolniczych rodzinnych jednostkach produkcyjnych.

Pomimo ustanowienia przepisów u.k.u.r. kwestia ustroju rolnego nie doczekała się dotychczas w prawie polskim kompleksowej regulacji. Do dziś jest to poważny mankament dostrzegany w doktrynie. Aktualna regulacja prawna w zasadzie nie określa także racjonalnej definicji gospodarstwa rodzinnego. Nie uwzględniając bowiem więzi rodzinnych, rodzinnych zasobów pracy, dochodów naturalnych jako podstawy utrzymania, w skrajnym przypadku pozwala uznać za gospodarstwo rodzinne singla gospodarującego na jednostce produkcyjnej spełniającej ustawowe kryterium obszarowe. Analizowane przepisy u.k.u.r. są jedynie namiastką definicji całkowicie oderwaną od rzeczywistości. Ustawodawca, posługując się kryteriami obszarowymi i podmiotowymi, nie doprowadził do właściwego odróżnienia tych gospodarstw na tle innych gospodarstw prywatnych. Choć w naukach ekonomicznych jako główne wyróżniki gospodarstwa rodzinnego przyjmuje się korzystanie z rodzinnych zasobów pracy oraz zarządzanie gospodarstwem przez członka rodziny, to polski ustawodawca tych najistotniejszych wyznaczników zdaje się nie zauważać. Związek gospodarstwa rolnego z domowym, więzi rodzinne i ochrona rodziny, wielopokoleniowość rodzin rolniczych, rodzinne zasoby pracy, ochrona 
zdolności do pracy w rolnictwie, stosunki własnościowe, rodzinne dochody oraz stosunki z następcą prawnym to istotne atrybuty rodzinnych gospodarstw rolnych.

Stworzenie nowej racjonalnej definicji legalnej gospodarstwa rodzinnego to zadanie, które wciąż wymaga należytego rozwiązania legislacyjnego, stanowiące wyzwanie dla nauki prawa rolnego. Warto wskazać, że w doktrynie postuluje się konieczność kompleksowej regulacji, najlepiej w odrębnej ustawie, sytuacji prawnej gospodarstwa rodzinnego, zwłaszcza na użytek dziedziczenia i obrotu nieruchomościami rolnymi (Wierzbowski, 2015, s. 375). Wymaga tego konstytucyjna potrzeba ochrony rodzinnych gospodarstw rolnych, które stanowią i mają stanowić w przyszłości podstawę ustroju rolnego w Polsce.

Ubezpieczenie społeczne rolników stworzono z konieczności ochrony rolników, także tych prowadzących gospodarstwa rodzinne. „Wydaje się, że przepisy ustawy ubezpieczeniowej powinny prowadzić do korzystnych przemian w strukturze agrarnej zbliżających ustrój rolny państwa do konstytucyjnego wzorca" (Wierzbowski, 2015, s. 375). Pozostaje jednak pytanie postawione na wstępie opracowania: na ile ochrona rolnictwa rodzinnego jest dziś w ustawie ubezpieczeniowej właściwie realizowana?

Ustawa o ubezpieczeniu społecznym rolników poprzez sformułowany w niej katalog podmiotowy dostrzega potrzebę ochrony rodziny rolnika w gospodarstwie rolnym. Są to jednak nieśmiało zakreślone ramy rodzinności. Ustawodawca w tym akcie prawnym nie wprowadził pojęcia gospodarstwa rodzinnego ani się nim nie posługuje. Nie przyznaje także z tego powodu jakiejś szczególnej ochrony tej kategorii gospodarstw. Można zatem stwierdzić, że analizowana ustawa, w szczególności ze względu na określony w niej katalog podmiotowy, dostrzega problem ochrony cech rodzinnych gospodarstwa rolnego. Nie chroni jednak wprost w sposób szczególny gospodarstw rodzinnych - nie wyszczególnia tej kategorii gospodarstw oraz nie oferuje instytucji preferencyjnych.

Przedmiotem ochrony rolniczego ubezpieczenia społecznego jest zdolność do zdobywania własną pracą środków utrzymania. Przedmiot ochrony wymaga ochrony ubezpieczonego ex ante i ex post (przed i po wystąpieniu zdarzenia ubezpieczeniowego), co sprowadza się do uregulowania kwestii BHP w rolnictwie i przekonstruowania ustawowych zadań KRUS w zakresie prewencji - tak, żeby była to prewencja realnego działania, przejawiająca się w bezpośrednim oddziaływaniu na niebezpieczeństwa występujące w konkretnym gospodarstwie rolnym. W gospodarstwach rodzinnych jest to zagadnienie szczególnie istotne dla rolnika zarządzającego gospodarstwem i rozdzielającego w nim pracę. Nie ulega wątpliwości, że kwestie te dotyczą ochrony każdej osoby faktycznie pracującej w rolnictwie. 
Z drugiej strony omawiana ustawa w szczególny sposób, inaczej niż w odniesieniu do innych ubezpieczonych rolników, nie chroni „głównego żywiciela rodziny” poza instytucją jednorazowego odszkodowania czy renty rodzinnej, przy czym dyskusyjna pozostaje również wysokość uzyskiwanego z tego tytułu świadczenia. Utrata zdolności do pracy „rolnika zarządzającego” gospodarstwem rolnym może mieć poważne znaczenie dla bytu tej jednostki produkcyjnej w przyszłości.

Niejednokrotnie zdarza się, że małżonkowie wspólnie prowadzą gospodarstwo rolne, przez co choroba nawet jednego $\mathrm{z}$ nich - nawet $\mathrm{z}$ uwzględnieniem zasiłku chorobowego - ani nie rekompensuje utraconych dochodów, ani nie zapewnia podtrzymania ciągłości produkcji. Stąd też powstaje realne zagrożenie dla dochodów rodziny i prowadzonej działalności rolniczej.

Podobnie będzie, jeżeli zajdzie konieczność skorzystania ze świadczenia macierzyńskiego. W konstrukcji przed nowelizacją przepisów zasiłek macierzyński przypominał premię porodową. Aktualnie świadczenie w wysokości $1000 \mathrm{zł} / \mathrm{mc}$ w mniejszych gospodarstwach rolnych może w części kompensować utratę uzyskanego dochodu, ale nie pozwala na zatrudnienie w pełnym wymiarze osoby do pomocy w celu podtrzymania produkcji rolnej. Macierzyństwo i osobista opieka nad dzieckiem to pozytywna przeszkoda w możliwości wykonywania pracy, która dotyczy wielu kobiet na wsi. Warto zauważyć jednak, że wsparcie rodzin programem Rodzina 500 plus może realnie uzupełnić braki w tej ochronie ubezpieczeniowej.

Kolejną kwestią istotną dla rolnictwa rodzinnego jest praca w nim wszystkich członków rodziny bez względu na wiek. Mając na uwadze regulacje niemieckie, francuskie czy włoskie, istnieje potrzeba ochrony wszystkich podmiotów faktycznie wykonujących pracę w rolnictwie przed utratą zdolności do pracy. Chodzi tu przede wszystkim o poruszany problem ochrony dzieci poniżej lat 16. Jednocześnie ustawa powinna należycie chronić osoby w wieku poprodukcyjnym poprzez właściwe stymulowanie zmian generacji w rodzinnych gospodarstwach rolnych. Regulacja nie czyni tego w sposób wystarczający z uwagi na zbyt niskie świadczenia emerytalne. $\mathrm{W}$ praktyce często nie pozwalają one dziadkom na całkowite wycofanie się z pracy rolniczej, nie wspominając już o wysokości świadczeń rentowych.

Zgodnie ze wskazanymi normami konstytucyjnymi istnieje dziś potrzeba ochrony rolnictwa rodzinnego. Wydaje się, że swoista ochrona rodzinnych gospodarstw powinna być przyznana przede wszystkim w szczególnym rolniczym ubezpieczeniu społecznym. Rodzina bowiem i jej byt jest szczególną kategorią ryzyka socjalnego, wielopodmiotowego. Dlatego to rodzinne gospodarstwa rolne w pierwszej kolejności zasługują na ochronę w systemie. Powinien być 
to bodziec do refleksji dla tych sceptyków, którzy podnoszą potrzebę likwidacji KRUS. Nie budzi zatem wątpliwości, że przyszła reforma zakresu podmiotowego ubezpieczenia powinna priorytetowo przyznać szczególną ochronę rolnictwu rodzinnemu. Kwestią wykraczającą poza ramy opracowania jest odpowiedź na pytanie, czy i na ile $w$ ramach tego ubezpieczenia na zasadzie solidarności zawodowej włączyć pracowników rolnych i przedsiębiorców rolnych, przy uwzględnieniu dywersyfikacji opłacanych przez nich składek.

Reasumując, ochrona rolnictwa rodzinnego jest niewystarczająca - i to nie tylko ze względu na brak racjonalnej definicji rodzinnego gospodarstwa rolnego oraz słabej realizacji norm konstytucyjnych w innych aktach prawnych, ale także na braki w rolniczym systemie ubezpieczenia społecznego. Na uznanie zasługuje niewątpliwie dostrzeżenie w ustawie ubezpieczeniowej atrybutów rodzinności w gospodarstwach rolnych. Jednak ze względu na swoistość pracy w działalności rolniczej ustawodawca zbyt słabo chroni dziś w ustawie ubezpieczeniowej rolnictwo rodzinne. Istotnym zadaniem sytemu jest ochrona tych wszystkich podmiotów, które faktycznie pracują w rolnictwie. Nie można jednak zapomnieć, że ochrona powinna być widoczna we wszystkich sferach ubezpieczenia - ochronnej, prewencyjnej, gwarancyjnej i kompensacyjnej. Nie wystarczy tu zatem stworzenie dobrej konstrukcji tego ubezpieczenia - dla poszkodowanego bowiem najczęściej najistotniejszą kwestię stanowi jakość uzyskiwanych świadczeń.

Z uwagi na wskazane normy konstytucyjne co najmniej zastanawiające jest, dlaczego polski ustawodawca do tej pory nie uwzględnił należycie atrybutów rolnictwa rodzinnego w żadnym $\mathrm{z}$ obowiązujących obecnie aktów prawnych ${ }^{9}$. Gospodarstwo rodzinne jest przecież jedną z najważniejszych, podstawowych instytucji polskiego prawa rolnego.

Istnieje więc potrzeba należytej ochrony rodzinnego gospodarstwa rolnego w ujęciu przedmiotowym, podmiotowym i funkcjonalnym. Rozważania wskazują na problem podstawowy, jakim jest niewłaściwe sformułowanie legalnej definicji gospodarstwa rodzinnego w obowiązującej regulacji prawnej. Wymaga to także szerszego objęcia w przyszłości regulacją prawną definicji gospodarstwa rolnego z uwzględnieniem stosunków osobowych oraz elementu pracy w gospodarstwie rolnym (Budzinowski, 1985, s. 70), a także wyraźnego i racjonalnego wyszczególnienia w polskim ustawodawstwie poszczególnych kategorii gospodarstw rolnych. Najważniejszymi uchybieniami są tu przede wszystkim nieuwzględnienie rodzinnych zasobów pracy - wkładu pracy rolnika

${ }^{9}$ Poza nieśmiałym zaznaczeniem takich zależności jak pokrewieństwo i powinowactwo w katalogu podmiotowym ustawy o ubezpieczeniu społecznym rolników. 
i członków jego rodziny - oraz faktu, iż dochody naturalne uzyskiwane z gospodarstwa rolnego stanowią podstawę utrzymania rodziny. Nie można zapomnieć, że pozbawienie członka rodziny zdolności do pracy w wyniku nieszczęśliwego zdarzenia losowego czy nawet w przypadku urodzenia dziecka wpływa bezpośrednio na zdolności wytwórcze, a w skrajnej sytuacji decyduje nawet o bycie rodzinnego gospodarstwa rolnego. Stąd też tak istotne dla rolnictwa rodzinnego jest zapewnienie właściwej ochrony przed utratą zdolności do pracy wszystkim podmiotom pracującym w działalności rolniczej w szczególnym subsystemie rolniczego ubezpieczenia społecznego.

\section{Bibliografia}

\section{Akty prawne}

Ustawa z dnia 20 grudnia 1990 r. o ubezpieczeniu społecznym rolników, t.j. Dz.U. 2020, poz. 174 ze zm.

Ustawa z dnia 2 kwietnia 1997 r., Konstytucja RP, Dz.U. nr 76, poz. 483.

Ustawa z dnia 11 kwietnia 2003 r. o kształtowaniu ustroju rolnego, t.j. Dz.U. 2019, poz. 1362. Ustawa o systemie ubezpieczeń społecznych, t.j. Dz.U. 2019, poz. 300 z późn. zm.

Ustawa z dnia 2 kwietnia 2004 r. o zmianie ustawy o społecznym ubezpieczeniu rolników oraz o zmianie niektórych ustaw, Dz.U. 2004, nr 91, poz. 873.

Ustawa z dnia 13 kwietnia 2018 r. o zmianie ustawy o ubezpieczeniu społecznym rolników oraz niektórych innych ustaw, Dz.U. 2018, poz. 858.

\section{Literatura}

Budzinowski, R. (1985). Rodzinny charakter indywidualnego gospodarstwa rolnego. Ruch Prawniczy, Ekonomiczny i Socjologiczny, 4, 63-74. https://doi.org/10.14746/ rpeis

Czechowski, P., Korzycka-Iwanow, M., Prutis, S., \& Stelmachowski, A. (1999). Polskie prawo rolne na tle ustawodawstwa Unii Europejskiej. Warszawa: LexisNexis.

Domańska, A. (2001). Konstytucyjne podstawy ustroju gospodarczego Polski. Warszawa: Wydawnictwo Sejmowe.

Jędrasik-Jankowska, I. (2003). Ubezpieczenie społeczne, część ogólna (t. 1). Warszawa: LexisNexis.

Kremer, E. (2004). Odpowiedzialność za zobowiązania związane z prowadzeniem gospodarstwa rolnego. Kraków: Zakamycze.

Król, M. A. (2015). Rozwiązania prawne w zakresie zabezpieczenia warunków pracy kobiet i przeciwdziałania wypadkom $\mathrm{z}$ udziałem dzieci w rolnictwie $\mathrm{w}$ aktach 
międzynarodowych i wybranych państwach europejskich. Ubezpieczenia $w$ Rolnictwie. Materiały i Studia, 53, 75-82.

Lichorowicz, A. (2000). Konstytucyjne podstawy ustroju rolnego RP w świetle art. 23 Konstytucji. Studia Iuridica Agraria, I, 23-45. https://doi.org/10.15290/sia

Lichorowicz, A. (2005). Regulacja obrotu gruntami rolnymi według ustawy z 11.iv.2003 r. o kształtowaniu ustroju rolnego na tle ustawodawstwa agrarnego Europy Zachodniej. Studia Iuridica Agraria, IV, 9-30. https://doi.org/10.15290/sia

Lichorowicz, A. (2015). Prawne pojęcie gospodarstwa rodzinnego w ustawodawstwie unijnym, krajów Europy zachodniej oraz w polskim ustawodawstwie rolnym. W: M. Podstawka (red.), Ekonomiczne i prawne mechanizmy wspierania i ochrony rolnictwa rodzinnego (s. 179-192). Warszawa: Fundacja Programów Pomocy dla Rolnictwa FAPA.

Prutis, S. (2005). Kształtowanie ustroju rolnego - potrzeba nowej regulacji ustawowej. Studia Iuridica Agraria, V, 168-174. https://doi.org/10.15290/sia

Prutis, S. (2013). Status prawny rodzinnego gospodarstwa rolnego w polskim prawie rolnym (ocena stanu regulacji). W: P. Litwiniuk (red.), Prawne mechanizmy wspierania i ochrony rolnictwa rodzinnego $w$ Polsce i innych państwach Unii Europejskiej (s. 11-22). Warszawa: Fundacja Programów Pomocy dla Rolnictwa FAPA.

Puślecki, D. (2009). Problem ochrony dzieci od wypadków przy pracy w rolnictwie. Przeglad Prawa Rolnego, 1, 193-209. https://doi.org/10.14746/ppr

Puślecki, D. (2011). Społeczne ubezpieczenie wypadkowe rolników. Zagadnienia prawne. Warszawa-Poznań: Juris.

Puślecki, D. (2016). Prawne pojęcie gospodarstwa rodzinnego. Zeszyty naukowe SERiA, 2, 201-207. https://doi.org/10.5604/paaae

Puślecki, D. (2018). Prawna ochrona dzieci pracujących w rodzinnym gospodarstwie rolnym na tle rozwiązań przyjętych w ustawodawstwie zachodnioeuropejskim. W: A. Stelmach (red.), Stosunki międzynarodowe w procesie zmian (s. 441-455). Poznań: UAM.

Rakoczy, R. (2015). Gospodarstwo rodzinne jako podstawa ustroju rolnego w świetle Konstytucji RP z 1997 roku. Przegląd prawa ochrony środowiska, 3, 9-33.

Stelmachowski, A. (2013). Modele własności i ich uwarunkowania społeczno-ustrojowe. W: E. Gniewek (red.), Prawo rzeczowe. System prawa prywatnego (t. 3, s. 217-336). Warszawa: C. H. Beck.

Wierzbowski, B. (2005). Gospodarstwo rodzinne jako podstawa ustroju rolnego w Polsce. Zeszyty Naukowe Wyższej Szkoły Suwalsko-Mazurskiej im. Papieża Jana Pawła II w Suwatkach, 11, 31-49.

Wierzbowski, B. (2015). Rolnik indywidualny w polskim i unijnym systemie ubezpieczeń społecznych. W: P. Litwiniuk (red.), Prawne mechanizmy wspierania i ochrony 
rolnictwa rodzinnego w Polsce i innych państwach Unii Europejskiej (s. 363-374). Warszawa: Fundacja Programów Pomocy dla Rolnictwa FAPA.

Winczorek, P. (2000). Komentarz do Konstytucji Rzeczypospolitej Polskiej z dnia 2 kwietnia 1997 r. Warszawa, Polska: LIBER.

Zdziennicki, B. (2013). Źródła prawa rolnego. W: P. Czechowski (red.), Prawo rolne (s. 61-65). Warszawa: Wolters Kulwer.

\section{Streszczenie}

Celem opracowania jest udzielenie odpowiedzi na pytanie, na ile system rolniczego ubezpieczenia społecznego chroni rolnictwo rodzinne. Chodzi tu o zagadnienie ochrony rodziny, która prowadząc wspólnie gospodarstwo rolne, zapewnia utrzymanie swoim członkom. Zagadnień tych nie sposób rozważyć w oderwaniu od przedmiotu ochrony ubezpieczenia i charakterystyki prowadzenia działalności rolniczej w rodzinnych gospodarstwach rolnych.

W konkluzji autor stwierdza, że z uwagi na brak racjonalnej definicji rodzinnego gospodarstwa rolnego, słabej realizacji norm konstytucyjnych w innych aktach prawnych, w tym w rolniczym systemie ubezpieczenia społecznego, ochrona tej kategorii gospodarstw w prawie polskim jest niewystarczająca. Ze względu na swoistość pracy w działalności rolniczej zbyt słabo w ustawie ubezpieczeniowej ustawodawca chroni rolnictwo rodzinne. Ochrona bytu gospodarstwa rolnego wymaga szczególnej troski o podmioty w nim pracujące, a urzeczywistniana jest głównie poprzez odpowiednią jakość uzyskiwanych świadczeń. Zachodzi zatem potrzeba należytej ochrony rodzinnego gospodarstwa rolnego, nie tylko w ujęciu przedmiotowym i funkcjonalnym, lecz przede wszystkim podmiotowym.

SŁoWA KLUCzowE: rolnictwo rodzinne, gospodarstwo rodzinne, ubezpieczenie społeczne rolników

\section{Summary}

The purpose of the present article is to answer the question to what extent the agricultural social security system provides protection for family farming. It is the issue of family protection, which, when running a farm together, provides subsistence for its members. These problems cannot be considered in isolation from the subject of insurance protection and characteristic features of farming in family farms.

In conclusion, the author states that due to the lack of a rational definition of a family farm, poor implementation of constitutional norms in other legal acts, including the agricultural social insurance system, protection of this category of farms in Polish law is insufficient. Taking into consideration the peculiarity of work in agricultural activity, family- based agriculture is offered too little protection in the insurance act. The security of the existence of a farm requires special protection of the entities working in it, and it is implemented mainly through the appropriate quality of services provided. There 
is now a need for the appropriate protection of a family-based farming, not only in terms of the subject matter and functionality, but in terms of personal scope, above all.

KEYWORDs: family-based agriculture, family farm, agricultural social insurance

Nota o autorze

Damian Puślecki - dr; Katedra Prawa i Organizacji Przedsiębiorstw w Agrobiznesie, Uniwersytet Przyrodniczy w Poznaniu; główne obszary działalności naukowej: rolnicze ubezpieczenia społeczne; e-mail: puslecki@up.poznan.pl; ORCID: 0000-0002-3363-649X. 